
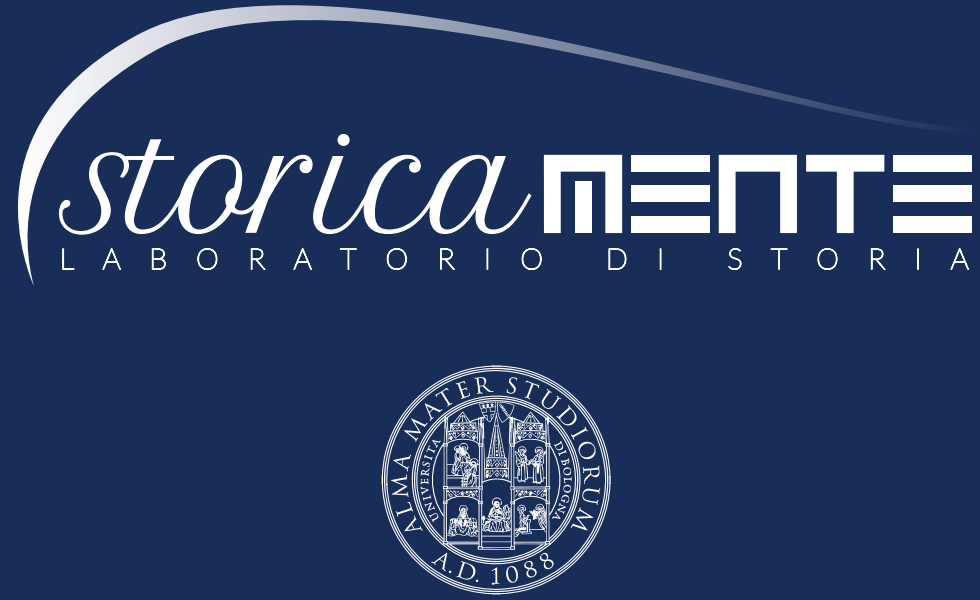

ALMA MATER STUDIORUM

Università di Bologna

Dipartimento di Storia Culture Civiltà

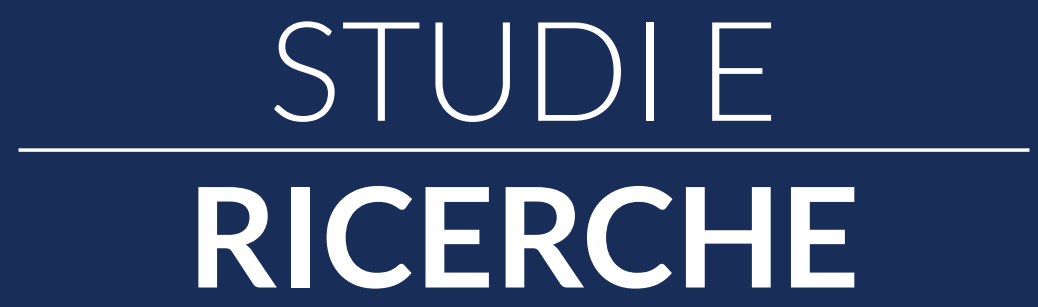

VIELLA 


\section{STORICAMENTE.ORG}

\section{Laboratorio di Storia}

Jean-Pierre Devroey

Social responses to climate change and extreme weather in the Age of Charlemagne (740-820)

(C) Jean-Pierre Devroey

Creative Commons BY-NC-ND 4.0

International License 2004- 2021

Volume: 2021

Issue: 17

Article number 2

Section: Studi e ricerche

Pages. 1-21

DOI: $10.52056 / 9788833138732 / 02$

ISSN: $1825-411 \mathrm{X}$

Publisher: Viella

Double blind peer review: Yes

Document type: Article

Research Areas: History

Published: 2021/10/08

Corresponding Address: Jean-Pierre Devroey, Université libre de Bruxelles, Département d'Histoire, Arts et Archéologie, Campus du Solbosch - CP 133/01, Avenue F.D. Roosevelt, 50, 1050, Bruxelles, Belgium 


\title{
Social Responses to Climate Change and Extreme Weather in the Age of Charlemagne (740-820)
}

\author{
Jean-Pierre Devroey \\ Université libre de Bruxelles, Département d'Histoire, Arts et Archéologie \\ jean-pierre.devroey@ulb.be
}

Over the past two decades, the growing availability of paleoclimatic data has opened new opportunities for cross-fertilisation and comparison between natural and social sciences. The parallel history of climate and the environment is often undertaken in a holistic manner, assuming simple and direct causalities between the climate and social change. Faced with climatic series, the historian must question the nature of the data and their specific conditions of gathering, validity, and environment, as well as the methods and objectives of modelling. Comparing paleoclimatic data and primary sources requires considering their specific limitations and finding a common scale of observation. A historical case study has just been conducted using climate series and sources from the age of Charlemagne (740-820 AD), a time interval of 80 years that is compatible with the heuristic requirements of both disciplines. The investigation confronts paleoclimatic data and interpretations with Frankish sources from 740 to 820, starting from the analysis of the famines of 779, 791-794 and recurrent subsistence phenomena at the beginning of the 9th century, studying in parallel cosmologies and representations, and the political, economic, and social responses brought by the political system.

KEYWORDS: CLIMATE CHANGE; CHARLEMAGNE; PALEOCLIMATIC DATA; FRANKISH SOURCES; FAMINES

For medievalists, investigating the interactions of climate - and the environment in general - with human societies requires working with sources that are at once laconic, patchy and scattered: we think of elusive mentions in letters or annals, but also of the proxy data used by paleo climatologists, which is necessarily incomplete and indirect (pollens, ice core, speleothems, sediments etc.). To what extent do these sources complement each other? Can a precise knowledge of the climate in the Carolingian period be based on them? This paper provides a first insight into the methodological and analytical framework discussed in my recent book and briefly presents its main results (Devroey 2019). 
Historians are challenged by the influx of paleoclimatic data and unwritten archives (I am obviously thinking of archaeology and the new tools offered by paleosciences: paleoanthropology, paleozoology, paleobotany, etc.). They offer new perspectives on the interactions and dynamics at work in the natural environment. The confrontation of written sources with serial data and modelling raises heuristic and epistemological questions (Slavin 2016; Degroot et al. 2021).

Using tree rings, dendrological reconstructions reach a degree of precision familiar to historians: was it hot or cold, dry or wet, during the summer or spring of the year of Charlemagne's imperial coronation in 800 , or during the autumn or winter of 814 , when he died? We cannot have the same confidence in the use of estimates of precipitation or temperature, whose values lie within a wide uncertainty interval. They do not identify extreme weather events with sufficient precision. If we add that these models incorporate hundreds of fossil trees, collected over a large geographical area, historians loses the geographical precision and at the same time the complexity of the event. I would say that historians focus on each individual tree, whereas paleoclimatologists want to identify and measure general spatial and chronological trends (Büntgen et al. 2011; M. McCormick et al. 2012; Cook et al. 2015). The massive pollution caused by major volcanic eruptions causes a global radiative forcing that results in a sharp drop in temperature over a period of months or years (as in the case of the sunless summer caused by the explosion of the Indonesian volcano Tambora in 1816) (D'Arcy Wood 2014). Sulphate pollution peaks in ice cores serve as a marker of intensity, but this time, the chronological precision is lacking, with dating ranges of $+/-5$ years in the 8 th- 9 th centuries! Apart from the fact that the primitive event is practically never reported in written sources, this temporal uncertainty makes the search for correlations very difficult (Gao, Robock, and Ammann 2008; Gao, Robock, and Ammann 2012; Sigl et al. 2015; Büntgen et al. 2016; Gao et al. 2016). For example, written sources of diverse geographical and cultural origin attest to the existence of a winter with extreme negative temperatures in the Black Sea, Anatolia, the Balkans, Southern France and North-Western Europe as far as Ireland in 763-764. The "terrible winter" of that year was probably not the result of a great volcanic explosion as some have argued in the past; cross-analysis of proxies and written sources points 
to the hypothesis of several causalities, linked in particular to anomalies in atmospheric circulations, and the existence of several episodes of intense cold, which were chronologically and geographically separated (M. McCormick, Dutton, and Mayewski 2007; Devroey 2019, 157-87).

While the use of models for reconstructing climate dynamics in the search for correlation and causality always proves to be perilous in terms of historical determinism (McIntosh, Tainter, and McIntosh 2000; Kostick and Ludlow 2013; 2015), these figures are an important tool for measuring how contemporary witnesses (and, beyond that, the society in which they live) perceived and reported on natural hazards (Alexandre 1974; Labbé 2017). With its exceptional diversity and richness, the corpus of Frankish historiographical sources from the decades 740 to 820 (which chronologically frame the life and reign of Charlemagne) provides an ideal field of observation, with a total of 51 original narrative sources in all, and an average of around twenty to thirty active sources (mentioning at least one event) per year. From the first catalogues of calamities that appeared in the 17th century to the end of the 20th century, historians have sought positive facts to be linked to natural events, mentioning meteorological, geological and astronomical phenomena, famines, diseases, etc. (Newfield 2011; Wozniak 2020). For the Frankish sources, such an analysis amounts to nearly 400 events. I have chosen to open up new methodological perspectives by also measuring the "silence" of the sources. This approach has proved to be a powerful tool to approach the way human groups and individuals perceive their physical and natural environment. In order to broaden the collection of information and to compare their various ecological susceptibilities, I extended the documentation to other cultural and geographical corpuses by screening contemporary Irish and British sources, Arab sources from the Western Mediterranean (Maghreb, Spain), Byzantine and Syriac sources. The whole collection represents a corpus of more than 750 events (Devroey 2019, 77-109).

Building this database makes it possible to categorise the different ways in which authors perceive and represent natural events in a given region according to their own culture and environment. The classification of meteorological events in the annals of north-western Europe shows that in Ireland and Great Britain, witnesses were most impressed 
by windy and stormy episodes (37\%) and by prolonged snow events (34\%)(Devroey 2019, 166, 171-172). On the Continent, in Francia, most witnesses mentioned the intensity of the cold and the length of the winter periods (54\%) and secondarily excessive rainfall. Depending on the geoclimatic regions, our witnesses selected atypical events according to the usual climate (Devroey 2019, 102-6). In Ireland, changes in atmospheric circulation caused an increase in tornadoes which frequently affect the island in autumn and winter; exceptionally heavy winter rainfall and persistent snow cover upset the agro-ecological balance at the end of the 8th century, undermining a society oriented and structured by livestock farming without winter stalls. At the turn of the 8th and 9th centuries, Irish society turned towards cereal farming. This ecological transformation led to the flourishing of mills and, at the social level, to an increase in the size of agro-pastoral farms and a rise in inequalities between the elite and the peasantry (F. McCormick 2008; Kerr, Swindles, and Plunkett 2009; F. McCormick et al. 2011; F. McCormick, Kerr, and O'Sullivan 2013; Devroey 2019, 171-5). Historians, when considering the impact of natural events on past societies, often think in terms of two different temporalities and causalities: the short-term disruptive effect of exceptional hazards, such as volcanic eruptions or pandemics, capable of upsetting the equilibrium or putting the existence of societies and empires at stake, and the long-term scale of periodic climatic oscillations that favour adaptations. Before the global warming caused by the massive use of fossil energies, the first and second millennium $\mathrm{AD}$ were characterised by three long-term climatic oscillations, after the Roman optimum (Le Roy Ladurie 1972; Jones and Mann 2004): (1) the Late Antique Little Ice Age, between the 3rd and 7th centuries (Büntgen et al. 2016; Helama, Jones, and Briffa 2017, see below, p. 6); (2) The Medieval Climate Anomaly with huge spatial and temporal variability on a global, but also European scale (Fairbridge 2009; Diaz et al. 2011); and (3) the modern Little Ice Age, from the 15th to the end of the 19th century (Le Roy Ladurie 2004). The challenge of "La Nature et le roi" lies in narrowing the focus to less than a century in order to analyse the complexity of the interactions between climate, environments, societies and political economies. (Kates 1987; Hannaford 2014; Devroey 2019, 58). The survey also draws its inspiration from micro-history by choosing subsistence 
crises as privileged observation points of the relations between power, environment and society (Menant 2007; Benito i Monclús 2007; Newfield 2013; Devroey 2016). This survey is conducted in the second part of the book around four key moments: the "terrible winter" of 763-764, the annual (779) or multiannual (791-794) famines of the late 8 th century, and the long period of crop failures and food crises of the years 800-824, which overlap with the end of Charlemagne's reign and the beginning of that of his son Louis the Pious. With its attention to detail and to all aspects the documentation sheds light on, this micro-historical approach makes it possible to show that famines are not only times of scarcity, challenging the reaction and resilience capacities of medieval societies. They are also periods of uncertainty during which the righteousness and fortune of the Christian sovereign are confronted with military setbacks. These were inflicted by pagans, Saxons or Saracens. The king's ability to govern was also challenged by theological disputes. Family dissensions of an intimate or political nature, such as the conspiracy of Pepin the Hunchback against his father and half-brothers in 792, also called into question the sovereign's righteousness. Charlemagne's responses to hunger were of course primarily religious and liturgical. They also aimed to increase the sovereign's impact on the economy and trade by coining a stable and strong currency (the new denarius of 793-794), renewing and standardizing weights and measures. They ensured the sale of royal grain at a moderate price, and imposed maximum prices for cereals and bread (Cândido 2014; Devroey 2016; Devroey 2019, 363-426).

What do we know about the climate at that time in the West? Was it warmer or colder, wetter or drier than the one we know?

Charlemagne's age is part of the Holocene, the geological period covering the last ten thousand years, up to the global warming accelerated by industrialization and the massive production of greenhouse gases that we are currently experiencing. This ten thousand year period is characterized by slow and periodic oscillations in the Earth's climate, with average temperature variations of less than about half a degree Celsius, on a decadal or secular scale! From this point of view, Charlemagne's age lies in an intermediate period between a colder and wetter climatic oscillation, whose minimum is in the middle of the 6th century, and the medieval optimum, which is marked in Europe by 
the higher average temperatures of the 11th-13th centuries. For the 8th-9th centuries, the vulnerability of natural and social ecosystems to climate variability in a given geoclimatic region needs to be measured according to an annual or multi-year scale. For the period from 740 to 840 and in Francia, where the dendrological archives are concentrated, the secular spring rainfall average is very close to that of today. However, this stability is misleading. While the first half-century from 740 to 790 is marked by small variations in spring rainfall, the second half is characterised by a significant increase towards progressively wetter weather in the empire of Charlemagne and Louis the Pious, which can be linked, in the written sources, to the multiplication of river floods in the north-west and successive crop failures between 805 and 809 (four years of scarcity out of five) and between 820 and 824 (Devroey 2019, $67-9,341-61)$. This crisis in agricultural productivity was aggravated by a panzootic that decimated cattle throughout Europe in 809-810, simultaneously affecting the farming assets and available food supplies (Newfield 2012; 2015). The existence of a centuries-old phenomenon of cooling summer temperatures in the north of the Frankish Empire, with a drop of $1.4^{\circ} \mathrm{C}$, combined with the increase in spring rainfall between 790 and 840 , favoured the coincidence of very unfavourable conditions for the growth of cereals in temperate climates (wet spring, cold summer) leading to crop failures. This climatic imbalance is accentuated by peaks in rainfall and the succession of harsh winters in the same region of Western Europe. Abrupt climatic disturbances on a decadal scale are particularly disruptive for agricultural societies, as they are difficult to absorb through stocks accumulated in favourable years or to offset through social or technological innovations. The impact of these medium-term climatic anomalies seems to be one of the key elements in the decrease of agricultural production during the first half of the ninth century in Western Europe, at a time when Francia was experiencing an economic depression (Verhulst 2002; Devroey 2011). Agricultural productivity seems to have been mainly affected by the repetition of bad weather during the years 805 to 809 and 820 to 824 . In addition to these recurring effects, other cascading effects must be added to measure the overall intensity of the crisis, notably the panzootic disease that struck the European cattle herd in 809-810 (Newfield 2012; 2015; Devroey 2017). 
At any given time, natural calamities are perceived and interpreted according to the available knowledge and systems of representation. How were these events perceived in the Early Middle Ages, and how were they explained?

Environmental history can be divided into three dimensions: (1) the dynamics of ecosystems, which includes the interaction of production methods (tools, work, social relations) with the environment; (2) the political economies (ideologies, ethics, laws, myths, etc.) that humans constitute within these systems; and, (3) the "cognitive eyeglasses" through which humans perceive and represent the dialogue and interchange of human groups with the other components of the ecosystems in which they live and perpetuate themselves (Cronon 1993; Worster 1994; Cronon 2016). The cross-reading of paleoclimatic data and written and archaeological sources opens up a particularly relevant angle for observing the interactions between them and considering how contemporaries perceived the "weather" and natural calamities. The Carolingian elites, mostly clerics, who wrote down these events, obviously used the narrative patterns and interpretative grids they drew in particular from the Old Testament to give meaning to the hazards, to insert them into sets of signs and portents and to develop strategies of response at the level of religion, morality and society. If Nature created by God is failing, it is because of human behaviour (Smith 2005). Confronted with the corruption of men, God grants or suspends the beneficial effects of Providence, and strikes them, because of their sins, iniquity or disobedience to the king. Since the Earth is the work of God, Nature is fundamentally generous. This promise of abundance, fertilized by the work of men, is one of the foundations of the royalty given by God to Israel and serves as a model for the providential kingship exercised by Charlemagne, whom his close relatives call willingly the "new David". The Carolingian king is thus invested with a function of religious and moral discipline, and his function as "shepherd" of men invites him to concern himself with the safety of each of his subjects (Devisse 1985; Noël 2001). The memory of Charlemagne will serve in the Great Century to Bossuet and the intellectuals of the Little Council to draw the figure and model the function and paternal solicitude of the Very-Christian King, Louis XIV (Preyat 2011). Among the narrative elements to be drawn from the Bible, it should be noted that the Carolingian period made little use of the story of 
Joseph, Pharaoh's minister, and of the granaries of plenty from which to draw during the "lean years". The figure of the good sheperd could also be used to illustrate another form of pastoral care, that of the bishop who watches over his sheep spiritually and materially (see for instance the life of Remi by Hincmar of Rheims). The metaphor of the separation of the wheat from the chaff is mostly taken up again from the 12th century onwards, and is mainly used to differentiate between the good and the bad Christians.

The history of the plagues of Egypt serves as a theological justification for the payment of tithes, made obligatory by Pepin III and Charlemagne, and as an illustration and interpretation grid for natural calamities (Devroey 2019, 203-4, 229-31). In 779, the letter to Charlemagne from the monk Cathwulf of Saint-Denis', after describing the "eight signs of divine favour" and exalting the victory of the young king over the Lombards in 774, lists the "eight columns of the just king", with a counterpoint mention of the "plagues" that would overwhelm a failing king and his kingdom:

If you observe these eight columns carefully, you will be king - for king comes from ruling [...] - and your reign will be blessed and the days of your life, your wife and your sons will be blessed. And then it shall be peace in the air and in the seasons, and the fruitfulness of the earth and the sea and all creatures that are born upon the earth and the sea, and you shall be ruler over many peoples in happiness, and your enemies shall fall before your face. [...] In return for the king's injustice, it will be the king's own misfortune, the discord with his wife and sons, famine for the peoples, pestilence, the barrenness of the land and the sea, a multitude of storms striking the fruits of the earth in various ways, and the king defeated by his enemies and driven out of his kingdom (Moore 1996; Garrison 1998; Story 1999).

This cosmology, which establishes a direct relationship between the king and Nature, can be traced back to non-Christian myths and stories from the Celtic cultural area. They were incorporated into the

Letter of Cathwulf to Charlemagne, c. 775, MGH Epistolae merovingici et karolini aevi, $2, \mathrm{n}^{\circ} 7,501-5$. 
Christian tradition through the Irish from the 7th century onwards (Devroey 2019, 224-31).

Among the earliest accounts of the hazards facing medieval man, the story of the Ten Plagues of Egypt (see above, p. 8) offered the broadest frame of reference for thinking about the role of Nature in the procession of calamities accompanying the visits of God and the trials (tribulations) he inflicted to warn and punish men for their sins. The ten plagues make it possible to justify the signs (water turned to blood) and plagues (vermin, atmospheric phenomena, hail, clouds of locusts and darkness, and diseases of men and livestock). The power of the interpretative model is further strengthened by St. Augustine's homology between the Ten Plagues and the Ten Commandments of the Decalogue, which shows how God strikes the violators of the Law2.

A micro-historical approach, and the use of the widest range of data and sources, is essential to understand the aetiology and dynamics of environmental crises, especially subsistence crises. Amartya Sen (Nobel Prize in Economics 1998) had already demonstrated that contemporary famines respond to a variety of stimuli: natural, mainly climatic shocks that cause crop failure on the one hand (Food availability decline, FAD); socio-economic processes on the other: these defeat the usual resource allocation mechanisms on which the concept of food security is based. The phenomena that cause food entitlements decline (FEDs) can be wars, mistaken political decisions, speculation and grain hoarding, consumer panic, distress migration, etc. (Sen 1982; Devroey, Wilkin, and Gautier 2013). Before the chemisation of agriculture in the 19th and 20th centuries, and in the low-yielding agrarian systems of the past, the main cause of structural food insecurity in the world was long-term processes of climate change, which caused declines in agricultural productivity to which producers had to respond by gradually adapting their environmental interactions, farming systems and food crops. Extreme weather events and short-term climate anomalies triggered other interactions from the political economies that humans formed within

Augustine of Hippo, Sermo VIII, de decem plagis Aegyptorum et decem praeceptis legis habitus... 
the ecosystems in which they lived. Of the six ecological crises that have affected the South and West of the European Continent and the British Isles in the century after 740, four have undoubtedly been triggered by climatic factors: prolonged drought in Spain and the Maghreb (744-755), extreme winter and cooling of temperatures in a wider geographical area from the Black Sea to Ireland around 763764 , heavy annual rainfall and lower temperatures between 805 and 824 mainly in the north of the Frankish Empire. Two other "great hungers" accompanied by mortality in 779 and 791-794 do not seem to respond to climatic shocks.

In 779 , the famine was probably local or multi-local and limited to the Rhine basin where Saxon incursions endangered the heart of the Frankish institutions and led to destruction, loss of population and crops, and distress migration. The disaster at Roncesvalles (778) may also have exacerbated the feelings of anxiety expressed by the Frankish witnesses (Ganshof 1944; Devroey 2019, 189-237).

Between 791 and 794, the absence of any significant climatic disruption and the multi-regional nature of the food crisis have led to look for other causalities. Two independent contemporary sources alluded to unnatural aspects of the crops. While harvests were expected to be normal or even plentiful, the harvesters were confronted with the massive presence of grains emptied of their nutrient content: "one could see and touch this false harvest of grains, but no one could eat it". Careful examination of the ancient and Judeo-Christian traditions that underpinned medieval representations of Nature did not reveal an archetypal thematic narrative of such "harvests without grain", nor did the indexes of contemporary folkloric themes. According to the formula popularized by Arthur Conan Doyle's The Sign of the Four, "when you have eliminated the impossible, whatever remains, however improbable, must be the truth". In this instance, a Syriac Christian source, the chronicle of Zuqnin, describes with a luxury of material detail the crop damage caused in Syria between 749 and 752 by insect pests, worms and cryptogamic diseases. According to their mode of action, these pathogens able to empty grains of their substance correspond to current

Annales mosellanes, 793. 
enemies of plant resources, dipterans such as midges, beetles, nematode worms, fungi (causing burning wind, rust, red mould) (Harrak 1999). With the exception of social insects, bees and ants, and direct pests that devour crops such as grasshoppers, medieval observers do not have the taxonomic tools that allow them to "think" these plant pathologies and identify their agents, hence the expression "untold enemies" that I borrowed from the great Italian historian Carlo Maria Cipolla (Cipolla 1986), who used this expression to describe epidemics and health structures in Italy from the Renaissance to the seventeenth century.

The universe of insects and microorganisms was not revealed to scientists until the scientific microscope was invented in the seventeenth century. In 1669, the Dutch biologist Jan Swammerdam spoke out against the theory of spontaneous insect generation, inherited from Aristotle, at the time when Antoni van Leeuwenhoek carried out the first experiments showing that cheese moths did not appear in the paste if it was protected from the air (Jorink 2006). In 1694, van Leeuwenhoek first described how a weevil works in the granaries of Amsterdam merchants: at this stage of development, "the pupa," he wrote, "pierces the husk of the grain to feed itself by emptying it of its contents". From this point, the investigation can be extended to other agro-ecological situations such as beetles that threaten the sustainability of major cereal crops in North America during the War of Independence and until the first decades of the 19th century. As William Cronon admirably showed, it is the entire system of agricultural development in the American British colonies that precipitates these catastrophes: 1) extensive agriculture and stockbreeding, 2) colonial monocultures; 3) the eradication of Amerindian farmers and their agro-ecological skills, 4) the opening-up of agricultural landscapes and the destruction of plant barriers, 5) the importation of unsuitable European practices, like "grazing pasture", 6) the proliferation of certain indigenous parasites in new ecological niches and the spread of invasive species transported from Europe, like the Hessian fly (Mayetiola destructor), or the brown rust spread by the planting of barberry to separate inhabited areas from fields and pastures (Cronon 2003). The "improbable" hypothesis of pre- and post-harvest pests opens up new research perspectives, especially in archaeology, where paleobotany and paleozoology make it possible to interpret fos- 
sil grain stigmas as the result of the action of nematode worms (Dark and Gent 2001; Ruas, Buisson, and Lemoine 2016)!

The Carolingians did not passively endure the natural and climatic hazards that threatened food production and distribution during their reign: the book points out the many measures adopted to allow people to "make a living", by setting prices or fighting against speculation and the hoarding of grains by the elites, for example. These policies herald those of the late Middle Ages, and attract a great deal of interest among modern agronomists in the eighteen Century. Did they effectively contain sustenance crises (Devroey 2016; Cândido 2014)?

The title I gave to the book, La nature et le roi, refers to the Carolingian king's rationale. It simultaneously fits into the isomorphism between his power as sovereign and the balance of the cosmos, and into the moral and political economy that determines his political action. By ordering liturgies against hunger or setting maximum prices for grain, Charlemagne did not act according to a "political" or "economic" agenda in the present-day sense, but in a way that was rational in terms of values. To transpose this concept from economic theory to historical analysis, litanies or fasting had no positive or negative externalities. Other actions, such as the introduction of the mandatory parish tithe, the standardization of weights and measures, the condemnation of hoarding or speculation, the regulation of the market, etc., were on the contrary rich in potential externalities: creating new rights of access (entitlements) for the poor (tithe), facilitating and controlling transactions, and condemning practices related to economic behaviour. Their efficiency is almost always impossible to evaluate from written sources and archaeological data.

These normative decisions correspond to top-down interventions aimed at achieving a certain stability in the food system. After the 9th century and perhaps the 10th-11th century in the Germanic Empire, centralized royal power seems to turn away from these security policies until the 17th century when they return to the forefront of governmentality, to use the words of Michel Foucaultt. It is in the urban en-

Lectures at the Collège de France, 1977-1978 (Foucault 2004; Agamben 2008; Dalarun 2012, 281-306). 
vironment that these principles of food "police" find their best illustration (Van Uytven 1984; Wilkin 2018). They represent the core of the supply policies that we can study in the towns of the Central Middle Ages, from the 13th century onwards, based on the moral economy of markets: priority given to consumer-citizens, the search for price regulation, the control of weights and measures and the control over the commercialisation of basic foodstuffs (bread, meat, wine, etc.), the building of a transparent market oriented towards consumers (Pirenne 1951; Devroey 2012). The moral economy of the subsistence market formed a complex balance between the interests of sellers and buyers. Moreover, it is rare that regulatory and control measures were directed exclusively towards the interests of a single category of market actors, consumers or sellers (Wilkin 2015).

Environmental history makes it possible to highlight the complexity of the interactions between natural environment and human societies. It underlines the need to look first and foremost at the vulnerability of the latter - in other words, to their adaptability and resilience (Cronon 1993). In this respect, my approach stands in contrast to some of the catastrophic visions that associate global warming with civilizational collapse (Haldon et al. 2018). The central question facing historians today, as with the Middle Ages, is to understand what makes a society vulnerable.

By escaping from the new climatic determinism, history is able to broaden the field of possible to other environmental or societal factors and thus to enrich the scope of interactions within the living world (beyond the theoretical separation between humans and "nature") (Descola 2015; Chouquer and Lézy 2006; Descola, Ingold, and Lussault 2014).

Sen's work and the emergence of the concept of vulnerability in the 1970s demonstrated on the basis of contemporary cases that most environmental or geological crises leading to the loss of fundamental rights were not the direct consequence of natural disasters leading to a decline in the availability of food (FAD) or other relief resources, but of economic and social disasters produced by serious disruption of entitlements to food and security (FED), making access to basic goods and services inaccessible to larger or smaller parts of the population (Sen 1982; Blaikie 2002; Engler 2012). For the Middle Ages, however, 
many historians follow the neo-determinism that asserts the prevalence of FADs caused by Malthusian shocks and natural hazards (Campbell 2016; Alfani and O Gráda 2017).

Low agricultural productivity obviously directly exposed early medieval societies to climate variability and natural hazards. The example of crop tithing, which gradually established itself as a universal tax in Christian Europe between the mid-eighth and twelfth centuries, shows that political actions were likely to reduce the vulnerability of agricultural societies. By keeping its products on the spot for a whole agricultural year, and by allocating one third to one quarter of the harvest to assist the poor, the tithe undeniably plays a role in reducing the impact of crop failures and makes a marginal contribution to broadening people's entitlements to food. In 1789, during the debates of the National Assembly on the abolition of seigneurial rights and the Tithe, voices were raised among rural members of Parliament to defend the continuation of this parochial structure. This sentiment reflected their scepticism about the security mechanisms that would be the responsibility of the new institutions of the Republic (Devroey 2010).

Current research on medieval agrarian systems also underlines the need for historians to emancipate themselves from the ideas spread since the 18th century by the Agronomists in France and Great Britain. They emphasized the technical superiority and greater productivity of large exploitations and reasoned agriculture, as opposed to peasant knowhow and practices, which were considered retrograde and inefficient. Such Promethean accents can be found in the writings of Marc Bloch and Georges Duby, at the time of the "Green Revolution" (Bloch 1931; Duby 1962).

In the village ecosystems on which agricultural production is based during the Middle Ages, the drivers of innovation and the resilience provided by agricultural practices now seem to be mainly the fact of the peasant and family farmers. These agricultural practices foster landscape partitioning, green barriers, polyculture and gardening. In order to protect themselves from seasonal hazards, the peasant favoured mixed cropping combining several cereals and leguminous plants. These "mixed" crops were more effective in reducing the effects of natural hazards and climatic variability on vegetation and animals than monocultures of more fragile crops, such as wheat. However, the sei- 
gniorial choices - which were aimed at satisfying the specific needs of wealthy consumers and providing commercial goods - were obviously not well suited to these mixed crops! Seigniorial agriculture was not space-saving and did not have a high degree of soil sustainability. Differences in crop choices between lords and peasants can be detected quite easily in the written and archaeological sources and reveal a topographical distribution and social morphology of the cultivated landscapes and terroirs. When working for themselves and according to their own logic, peasant farmers exploited those parts of the village ecosystem that allowed the best adaptation to climate variability, environmental change and the household life cycle. In the ninth century, in bipartite estates which included both seigneurial demesne and family farms occupied by dependents, the lord provided neither the tools nor the cattle required for permanent farming. These came from the "peasant ecosystem", which was infinitely more varied and better equipped than its seigneurial counterpart. Dedicated to extensive practices and under-equipped in human and animal resources, the seigniorial lands were the object of permanent nibbling by peasants, eager to expand their own arable lands.

In an attempt to provide an answer to the challenging question of vulnerability, the Middle Ages suggest that we should look at certain features of human interactions with Nature: the "monotony" of agricultural practices and the indifference that it establishes in exchanges with Nature, the effects of an extractive dynamic, which favours objectives of power and wealth to the detriment of the complexity and diversity of interactions that humans can maintain "in sympathy and symbiosis" with their environment.

Wickham 2005, 536-7; Devroey 2011; Schroeder 2019; Devroey 2019, 332, $443-8$. 


\section{Bibliography}

Agamben, Giorgio. 2008. Le règne et la gloire. Pour une généalogie théologique de l'économie et du gouvernement (Homo Sacer, II, 2). Translated by Joël Gayraud and Martin Rueff. Paris: Seuil.

Alexandre, Pierre. 1974. "Histoire du climat et sources narratives du Moyen Âge." Le Moyen Âge 80 (1): 101-16.

Alfani, Guido, and Cormac Ó Gráda, eds. 2017. Famine in European History. Cambridge: Cambridge University Press.

Benito i Monclús, Pere. 2007. "Et si sterilitas, ut solet, in terra illa fuerit... Frecuencia, longevidad y gravedad de la carestias en Cataluna durante la 'fase de crecimiento' de la Economia medieval (siglos XI-XIII)." In Crisis de subsistencia y crisis agrarias en la Edad Media, edited by Francois Menant, H.R. Oliva Herrer, and Pere Benito i Monclús, 79-110. Sevilla: Presses de l'université de Séville.

Blaikie, Piers M. 2004. At Risk: Natural Hazards, Peoples Vulnerability and Disasters. London-New York: Routledge.

Bloch, Marc. 1931. Les caractères originaux de l'Histoire Rurale Française. Paris: Armand Colin.

Büntgen, Ulf, Vladimir S. Myglan, Fredrik C. Ljungqvist, Michael McCormick, Nicola D. Cosmo, Michael Sigl, Johann Jungclaus et al. 2016. "Cooling and Societal Change during the Late Antique Little Ice Age from 536 to around 660 AD." Nature Geoscience 9 (3): 231-6.

Büntgen, Ulf, Willy Tegel, Kurt Nicolussi, Michael McCormick, David Frank, Valerie Trouet, Jed O. Kaplan et al. 2011. "2500 Years of European Climate Variability and Human Susceptibility." Science 331 (6017): 578-82.

Campbell, Bruce. 2016. The Great Transition: Climate, Disease and Society in the Late-Medieval World. Cambridge: Cambridge University Press.

Cândido, Marcelo. 2014. "L'économie morale carolingienne (fin VIII -début IX" siècle)." Médiévales 66: 159-78.

Chouquer, Gérard, and Emmanuel Lézy. 2006. "Autour du livre de Philippe Descola." Etudes rurales 178: 229-52.

Cipolla, Carlo Maria. 1986. Contro un nemico invisibile. Epidemie e strutture sanitarie nell'Italia del Rinascimento. Bologna: Il Mulino.

Cook, Edward R., Richard Seager, Yochanan Kushnir, Keith R. Briffa, Ulf Büntgen, David Frank, Paul J. Krusic et al. 2015. "Old World Megadroughts and Pluvials during the Common Era." Science Advances 1 (10): e1500561.

Cronon, William. 1993. "The Uses of Environmental History." Environmental History Review 17: 1-22.

-. 2003. Changes in the Land. Indians, Colonists, and the Ecology of New England. New York: Hill and Wang (1st revised edition).

-. 2016. Nature et récits. Essais d'histoire environnementale. Translated by Mathias Lefèvre. Bellevaux: Editions Dehors. 
Dalarun, Jacques. 2012. Gouverner c'est servir: essai de démocratie médiévale. Paris: Alma. D'Arcy Wood, Gillen. 2014. Tambora: The Eruption That Changed the World. Princeton: Princeton University Press.

Dark, Petra, and Henry Gent. 2001. "Pests and Diseases of Prehistoric Crops: A Yield 'Honeymoon' for Early Grain Crops in Europe?” Oxford Journal of Archaeology 20 (1): 59-78. doi:10.1111/1468-0092.00123.

Degroot, Dagomar, Kevin Anchukaitis, Martin Bauch and Jakob Burnham. 2021. "Towards a Rigorous Understanding of Societal Responses to Climate Change." Nature 591: 539-50.

Descola, Philippe. 2015. Par-delà nature et culture. Paris: Gallimard.

Descola, Philippe, Tim Ingold, and Michel Lussault. 2014. Être au monde. Quelle expérience commune? Débat présenté par Michel Lussault. Lyon: Presses universitaires de Lyon.

Devisse, Jean. 1985. "Le sacre et le pouvoir avant les carolingiens. L'héritage wisigothique." In Le sacre des rois. Actes du colloque international d'histoire sur les sacres et couronnements royaux (Reims, 9-12 octobre 1975), 27-38. Poitiers: CESCM.

Devroey, Jean-Pierre. 2010. "Dîme et économie des campagnes à l'époque carolingienne." In La dîme dans l'Europe médiévale et moderne, edited by Roland Viader, 37-62. Toulouse: Presses Universitaires du Mirail.

-. 2011. "Perception de la nature productive et aspects des paysages ruraux à SaintRemi de Reims au IX siècle." Revue belge de philologie et d'histoire 89 (1-2): 267-94.

-. 2012. "Food and Politics." In A Cultural History of Food in the Medieval Age, edited by Massimo Montanari, 73-90. London: Berg.

-. 2016. "La politique annonaire des Carolingiens comme question économique, religieuse et morale." In L'Alimentazione nell'Alto Medioevo. Pratiche, simboli, ideologie. Atti CISAM 63 (Spoleto, 9-14 aprile 2015), 299-354. Spoleto: CISAM.

-. 2017. "L'économie carolingienne est-elle cyclique?" In La productivité d'une crise. Le règne de Louis le Pieux (814-840) et la transformation de l'Empire carolingien, edited by Philippe Depreux and Stefan Esders, 249-58. Ostfildern: Thorbeke.

-. 2019. La nature et le roi. Environnement, pouvoir et société à l'âge de Charlemagne (740-820). Paris: Albin Michel.

Devroey, Jean-Pierre, Alexis Wilkin, and Alban Gautier. 2013. "Agricultural Production, Distribution and Consumption around the North Sea, 500-1000." In The Rural Economy and Society in North-Western Europe, 500-2000. The Agro-Food Market: Production, Distribution and Consumption, edited by Leen Van Molle and Yves Segers, 3, 13-68. Turnhout: Brepols.

Diaz, Henry F., Ricardo Trigo, Malcolm K. Hughes, Michael E. Mann, Elena Xoplaki, and David Barriopedro. 2011. "Spatial and Temporal Characteristics of Climate in Medieval Times Revisited." Bulletin of the American Meteorological Society 92 (11): 1487-500. doi:10.1175/BAMS-D-10-05003.1.

Duby, Georges. 1962. L'économie rurale et la vie des campagnes dans l'Occident médiéval (France, Angleterre, Empire, IX ${ }^{e}-X V^{e}$ siècles). Essai de synthèse et perspectives de recherches. 1-2. Paris: Aubier. 
Engler, Steven. 2012. "Developing a Historically Based 'Famine Vulnerability Analysis Model' (FVAM) - An Interdisciplinary Approach." Erdkunde 66 (2): 157-72.

Fairbridge, Rhodes W. 2009. "Medieval Warm Period." In Encyclopedia of Paleoclimatology and Ancient Environments, edited by Vivien Gornitz. Dordrecht: Springer. https://doi.org/10.1007/978-1-4020-4411-3_137.

Foucault, Michel. 2004. Sécurité, territoire, population: cours au collège de France, 19771978, edited by Michel Senellart. Paris: Seuil.

Ganshof, François-Louis. 1944. "Une crise dans le règne de Charlemagne, les années 778 et 779." In Mélanges d'histoire et de littérature offerts à Charles Gilliard à l'occasion de son soixante-cinquième anniversaire, 133-145. Lausanne: Rouge.

Gao, Chaochao, Francis Ludlow, Or Amir, and Conor Kostick. 2016. "Reconciling Multiple Ice-Core Volcanic Histories: The Potential of Tree-Ring and Documentary Evidence, 670-730 CE." Quaternary International 394: 180-93.

Gao, Chaochao, Alan Robock, and Caspar Ammann. 2008. "Volcanic Forcing of Climate over the Past 1500 Years: An Improved Ice Core-Based Index for Climate Models." Journal of Geophysical Research: Atmospheres 113 (D23): 1-15. doi:10.1029/ 2008JD010239.

Gao, Chaochao, Alan Robock, and Caspar Ammann. 2012. Ice-Core-Based Volcanic Atmospheric Injection and Loading for the Past 1500 Years. New Brunswick: Rugers University. http://climate.envsci.rutgers.edu/IVI2/.

Garrison, Mary. 1998. "Letters to a King and Biblical Exempla: The Examples of Cathwulf and Clemens Peregrinus." Early Medieval Europe 7: 305-28.

Haldon, John, Hugh Elton, Sabine R. Huebner, Adam Izdebski, Lee Mordechai, and Timothy P. Newfield. 2018. "Plagues, Climate Change, and the End of En Empire: A Response to Kyle Harper's The Fate of Rome (1): Climate." History Compass 16. https://doi.org/10.1111/hic3.12508.

Hannaford, Matthew. 2014. "Climate, Causation and Society: Interdisciplinary Perspectives from the Past to the Future." In Selected Themes in African Development Studies: Economic Growth, Governance and the Environment, edited by Lucky Asuelime, Joseph Yaro and Suzanne Francis, 7-25. Cham-Heidelberg-New York-Dordrecht-London: Springer International Publishing.

Harrak, Amir. 1999. The Chronicle of Zuqnin, Parts III and IV. Toronto: Pontifical Institute of Medieval Studies.

Helama, Samuli, Phil D. Jones, and Keith R. Briffa. 2017. "Limited Late Antique Cooling." Nature Geosci 10 (4): 242-3.

Jones, Philip D., and Michael E. Mann. 2004. "Climate over Past Millennia." Reviews of Geophysics 42 (2): 1-42. doi:10.1029/2003RG000143.

Jorink, Eric. 2006. Reading the Book of Nature in the Dutch Golden Age, 1575-1715. Leiden: Brill.

Kates, Robert W. 1987. "The Interaction of Climate and Society.” In Climate Impact Assessment: Studies of the Interaction of Climate and Society, edited by Robert W. Kates, Jesse H. Ausubel and Mimi Berberian, 3-36. Chichester-New York: Wiley. 
Kerr, Thomas R., Graeme T. Swindles, and Gill Plunkett. 2009. "Making Hay While the Sun Shines? Socio-Economic Change, Cereal Production and Climatic Deterioration in Early Medieval Ireland." Journal of Archaeological Science 36: 2868-74.

Kostick, Connor, and Francis Ludlow. 2013. "European Weather Extreme in the Lifetime of Charlemagne (c.742-814 CE)." In First Annual Virtual Symposium on Pre-Modern Studies: Catastrophe, Calamity and Chaos in the Pre-Modern World, edited by the Medieval and Modern Institute (MEMI) at the University of Alberta and Athabasca University, 1-18. Edmonton: University of Alberta.

-. 2015. "The Dating of Volcanic Events and Their Impact upon European Society, 400-800 CE." Post-Classical Archaeologies 5: 7-30.

Labbé, Thomas. 2017. Les catastrophes naturelles au Moyen Âge. Paris: CNRS.

Le Roy Ladurie, Emmanuel. 1972. Times of Feast, Times of Famine: A History of Climate since the Year 1000. Translated by Barbara Bray. London: Allen \& Unwin.

-. 2004. Histoire humaine et comparée du climat, 1. Canicules et glaciers (XIII ${ }^{e}-X V I I I^{e}$ siècle). Paris: Fayard.

McCormick, Finbar. 2008. "The Decline of the Cow: Agricultural and Settlement Change in Early Medieval Ireland." Peritia 20: 209-24.

McCormick, Finbar, Thomas R. Kerr, Meriel McClatchie, and Aidan O'Sullivan. 2011. The Archaeology of Livestock and Cereal Production in Early Medieval Ireland, $A D$ 400-1100. Dublin.

McCormick, Finbar, Thomas R. Kerr, and Aidan O'Sullivan. 2013. The Economy of Early Medieval Ireland. Dublin: EMAP.

McCormick, Michael, Ulf Büntgen, Mark A. Cane, Edward R. Cook, Kyle Harper, Peter Huybers, Thomas Litt et al. 2012. "Climate Change during and after the Roman Empire: Reconstructing the Past from Scientific and Historical Evidence." Journal of Interdisciplinary History 43 (2): 169-220. doi:10.1162/JINH_a_00379.

McCormick, Michael, Paul E. Dutton, and Paul A. Mayewski. 2007. "Volcanoes and the Climate Forcing of Carolingian Europe, A.D. 750-950." Speculum 82 (4): 865-94.

McIntosh, Roderick J., Joseph A. Tainter, and Susan K. McIntosh, eds. 2000. The Way the Wind Blows: Climate Change, History, and Human Action. New York: Columbia University Press.

Menant, Francois. 2007. "Crisis de subsistencia y crisis agrarias en la Edad Media: algunas reflexiones previas." In Crisis de subsistencia y crisis agrarias en la Edad Media, edited by H.R. Oliva Herrer and Pere Benito i Monclús, 17-60. Sevilla: Presses de l'université de Séville.

Moore, Michael E. 1996. "La monarchie Carolingienne et les anciens modèles Irlandais." Annales. Histoire, Sciences Sociales 51: 307-24.

Newfield, Timothy. 2011. "The Contours of Disease and Hunger in Carolingian and Early Ottonian Europe (c.750-c.950 CE).” Ph.D. Thesis. Montréal: Mc Gill University.

-. 2012. "A Great Carolingian Panzootic: The Probable Extent, Diagnosis and Impact of an Early Ninth-Century Pestilence." Argos 46: 200-10. 
-. 2013. "The Contours, Frequency and Causation of Subsistence Crises in Carolingian Europe (750-950 CE)." In Crisis alimentarias en la Edad Media: modelo, explicationes y representaciones, edited by Pere Benito i Monclús, 117-72. Lleida: Milenio.

-. 2015. "Human-Bovine Plagues in the Early Middle Ages." Journal of Interdisciplinary History 46 (1): 1-38.

Noël, René. 2001. "Charlemagne et la morale du pouvoir." In Rêves de Chrétienté. Réalités du monde. Imaginaires catholiques. Actes du colloque (Louvain-la-Neuve, 4-6 novembre 1999), edited by Laurence Van Ypersele and Anne-Dolorès Marcélis, 5981. Louvain: Presses Universitaires de Louvain.

Pirenne, Henri. 1951. "Le Consommateur Au Moyen Âge." In Histoire Économique de l'Occident Médiéval, by Henri Pirenne, 532-4. Bruges: Desclée De Brouwer.

Preyat, Fabrice. 2011. "La renovatio carolingienne, matrice de la monarchie très chrétienne: The Carolingian Reform, the Matrix for the Very Christian Monarchy." Revista de Historiografia 8 (1): 85-109.

Ruas, Marie-Pierre, Alain Buisson, and Michel Lemoine. 2016. "Vestiges élucidés d'un parasite des céréales : les galles d'anguillule (Anguina sp.) dans les assemblages archéobotaniques médiévaux en France." In Plantes, produits végétaux et ravageurs. Actes des Xe Rencontres d'Archéobotanique, Les Eyzies-de-Tayac, 24-27 septembre 2014, edited by Marie-France Dietsch-Sellami, Charlotte Hallavant, Laurent Bouby and Bénédicte Pradat, 43-64. Bordeaux: Aquitania.

Schroeder, Nicolas. 2019. "Interagir avec des céréales, des sols, des intempéries et des nuisibles. Réflexions pour contribuer à une anthropologie de l'agriculture médiévale." In Pour une anthropologie historique de la nature, edited by Jérôme Lamy and Romain Roy, 137-48. Rennes: Presses universitaires de Rennes.

Sen, Amartya. 1982. Poverty and Famines: An Essay on Entitlement and Deprivation. Oxford: Clarendon press.

Sigl, Michael, Mai Winstrup, Joseph R. McConnell, Kees C. Welten, Gill Plunkett, Francis Ludlow, Ulf Büntgen et al. 2015. "Timing and Climate Forcing of Volcanic Eruptions for the Past 2,500 Years.” Nature 523 (7562): 543-9.

Slavin, Philip. 2016. "Climate and Famines: A Historical Reassessment." Wiley Interdisciplinary Reviews: Climate Change 7 (3): 433-47. doi:10.1002/wcc.395.

Smith, Julia M.H. 2005. Europe after Rome. A New Cultural History, 500-1000. Oxford: Oxford University Press.

Story, Joanna. 1999. "Cathwulf, Kingship, and the Royal Abbey of Saint-Denis." Speculum 74: 1-24.

Van Uytven, Roger. 1984. "L'approvisionnement des villes des anciens Pays-Bas au moyen âge." In L'approvisionnement des villes de l'Europe occidentale au Moyen Âge et aux Temps Modernes, 75-116. Toulouse: Presses Universitaires du Midi.

Wickham, Chris. 2005. Framing the Early Middle Ages. Europe and the Mediterranean, 400-800. Oxford: Oxford University Press.

Wilkin, Alexis. 2015. "Time Constraints on Market Activity and the Balance of Power in Medieval Liège." Continuity and Change 30: 315-40. 
-. 2018. "Organiser l'approvisionnement urbain: gestion des flux alimentaires, régulation des espaces d'échanges. Quelques réflexions en guise de conclusion." In $A p-$ provisionner la ville. Flux alimentaires et circulations urabaines du Moyen Âge au XIXe siècle, edited by Arnaud Knaepen, Christophe Loir and Alexis Wilkin, 191-203. Bruxelles: Editions de l'Université de Bruxelles.

Worster, Donald. 1994. "Nature and the Disorder of History." Environmental History Review 18: 1-15.

Wozniak, Thomas. 2020. Naturereignisse im frühen Mittelalter. Das Zeugnis der Geschichtsschreibung vom 6. bis 11. Jahrhundert, Berlin, Boston: De Gruyter, Oldenbourg. 